\title{
Effect of Enkephalins and Morphine on Insulin Secretion from Isolated Rat Islets
}

\author{
I. C. Green 1 , D. Perrin' ${ }^{1}$, K. C. Pedley ${ }^{2}$, R. D. G. Leslie ${ }^{3}$, and D. A. Pyke \\ ${ }^{1}$ Department of Biochemistry, School of Biological Sciences, The University of Sussex, Brighton, Sussex, ${ }^{2}$ Department of Biochemistry, \\ Charing Cross Hospital Medical School, London, and ${ }^{3}$ Diabetic Clinic, Kings College Hospital, London, England
}

Summary. The direct effects of an enkephalin analogue, (D-Ala ${ }^{2} / \mathrm{MePhe}^{4} / \mathrm{Met} /(\mathrm{O})$-o1) enkephalin (DAMME), on insulin release from isolated islets of Langerhans of the rat have been investigated. DAMME had a dose-dependent effect on insulin secretion: low concentrations $\left(10^{-10}\right.$ to $\left.10^{-8} \mathrm{~mol} / \mathrm{l}\right)$ were stimulatory while high concentrations $\left(10^{-5} \mathrm{~mol} / \mathrm{l}\right)$ were inhibitory in the presence of $8 \mathrm{mmol} / 1$ glucose. Similar effects were found with met-enkephalin, and with the longer acting alanine substituted metenkephalin. Morphine sulphate $\left(5 \times 10^{-7} \mathrm{~mol} / \mathrm{l}\right)$ also stimulated insulin release. The effects of enkephalin and morphine were blocked by the specific opiate antagonist naloxone hydrochloride $\left(1.2 \times 10^{-6} \mathrm{~mol} /\right.$ 1). The insulin secretory response of perifused islets to enkephalins and morphine was rapid, corresponding to the first phase of glucose induced insulin release. These observations suggest that there may be opiate receptors in islets, and that opioid peptides could modulate insulin release.

Key words: Enkephalins, morphine, insulin secretion, isolated rat islets, islet perifusion, diabetes.

Chlorpropamide-alcohol facial flushing (CPAF) was found by Leslie et al. [1,2] to occur in a proportion of non-insulin dependent diabetics. It was subsequently suggested [3] that CPAF might be related to sensitivity to enkephalin as it was reproduced in some cases by an enkephalin analogue and blocked by the specific opiate antagonist naloxone. The enkephalins are pentapeptides whose sequence is found in Bendorphin, and whose effects are similar to those of morphine. Morphine causes hyperglycaemia if given in large doses intravenously, or in smaller doses into the cerebral ventricles, the effect being centrally mediated [4]. Intraventricular B-endorphin also causes hyperglycaemia [5].

It was obviously of interest to know whether opioid peptides had any peripheral effects on the regulation of blood glucose levels. It has recently been shown that the release of insulin from the isolated perfused dog pancreas is stimulated by B-endorphin and morphine [6], while immunocytochemical studies suggest the presence in the pancreas of opiate receptors [7]. Direct effects of enkephalins or morphine on insulin secretory responses of isolated islets of Langerhans have not so far been reported. We have therefore examined the islet response to the enkephalin analogue, DAMME, previously used in clinical studies [3].

\section{Methods}

Isolated islets of Langerhans were prepared by collagenase digestion of pancreas from fed Sprague Dawley rats, or for islet perifusion, from fed Wistar rats (8). Islets from two rats were pooled on any one day. The effects of DAMME, (D Ala ${ }^{2} / \mathrm{MePhe}^{4} / \mathrm{Met} /(\mathrm{O})$ o1) enkephalin, (FK 33.824 Sandoz, Basle), met-enkephalin (Miles Laboratories, Slough, U. K.), D-Ala ${ }^{2} /$ met enkephalin (U. C. B. Christiaens Bioproducts, Brussels), morphine sulphate, (Evans Medical, Liverpool) and naloxone hydrochloride (Narcan, Winthrop, Surbiton on Thames, Surrey) on islet insulin release in vitro were tested as described previously [9]. Briefly, groups of 3 islets were incubated in $0.6 \mathrm{ml}$ of bicarbonate buffered medium, $\mathrm{pH} 7.4,[10]$ containing glucose $(8 \mathrm{mmol} / \mathrm{l})$ and albumin $(1 \mathrm{mg} / \mathrm{ml})$ with and without different concentrations of test substances. After a $30 \mathrm{~min}$ incubation an aliquot of medium was removed and diluted for insulin assay.

The islet'perifusion system consisted of a multichannel peristaltic pump, (Gilson, Villiers-le-Bel, France), in which 6 channels were used simultaneously to perifuse groups of 50 islets attached to nylon gauze in Millipore chambers (Millipore S. A., Molsheim, France). The flow rate was $1 \mathrm{ml} / \mathrm{min}$. Each chamber containing islets was perifused for $40 \mathrm{~min}$ in medium containing glucose $(6 \mathrm{mmol} / \mathrm{l})$ before the start of the experiment. Samples were then collected every $2 \mathrm{~min}$ for $10 \mathrm{~min}$ to record baseline insulin release. 


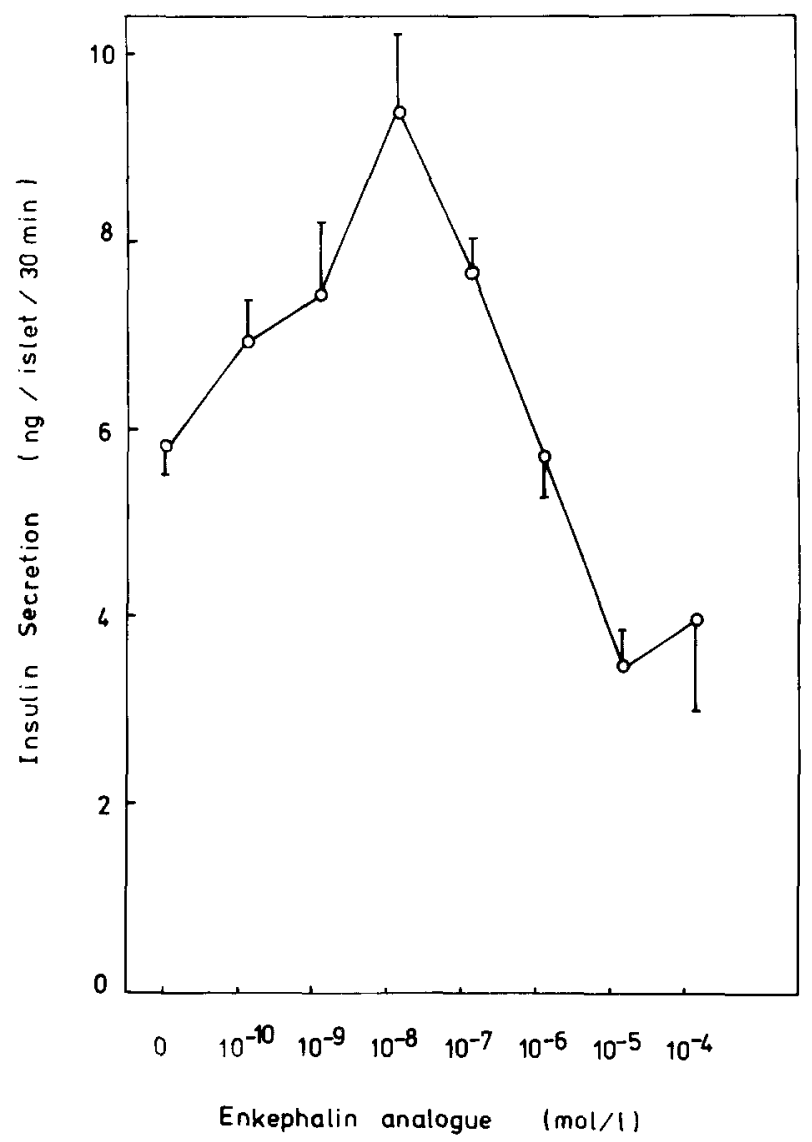

Fig. 1. Insulin secretion from isolated islets of Langerhans in response to increasing concentrations of an enkephalin analogue, DAMME in the presence of $8 \mathrm{mmol} / \mathrm{l}$ glucose. Each point represents the mean \pm SEM of 8-12 observations of insulin secretion over $30 \mathrm{~min}$, from a minimum of 2 experiments

The test substance was then added to the perifusate, and the effluent was collected every 1 or $2 \mathrm{~min}$ for $30 \mathrm{~min}$ at least.

Insulin was measured by double antibody radioimmunoassay, using rat insulin standards (Novo), insulin binding reagent (Wellcome Laboratories, Beckenham, Kent) and ${ }^{125} \mathrm{I}$-insulin prepared in the Sussex Laboratory. Results are stated as mean \pm SEM. Statistical analysis was by Student's ' $t$ ' test.

\section{Results}

Insulin secretion from isolated islets was stimulated by low enkephalin concentrations $\left(10^{-10}-10^{-7} \mathrm{~mol} / 1\right.$ DAMME, Fig. 1). Stimulation was abolished and subsequently reversed by increasing concentrations of enkephalin. When naloxone was added to the incubation medium the stimulatory effects of $10^{-8} \mathrm{~mol} / \mathrm{l}$ enkephalin were blocked reducing insulin release from $8.9 \pm 0.9$ to $5.7 \pm 0.6 \mathrm{ng} /$ islet $/ 30 \mathrm{~min}$. The secretory responses of islets to other enkephalins
Table 1. Insulin release from isolated rat islets incubated for $30 \mathrm{~min}$ in a medium containing $8 \mathrm{mmol} / \mathrm{l}$ glucose, unless stated otherwise, and different concentrations of enkephalin, morphine sulphate and naloxone hydrochloride. Results are given as mean \pm SEM of 6 groups of islets

\begin{tabular}{|c|c|c|}
\hline Addition to medium & $\begin{array}{l}\text { Concentration of } \\
\text { addition } \mathrm{mol} / 1\end{array}$ & $\begin{array}{l}\text { Insulin release } \\
\text { ng/islet } / 30 \mathrm{~min}\end{array}$ \\
\hline $\begin{array}{l}\text { Met enkephalin } \\
\text { Met enkephalin } \\
\text { Met enkephalin } \\
\text { None (control) }\end{array}$ & $\begin{array}{l}1.6 \times 10^{-9} \\
1.6 \times 10^{-8} \\
1.6 \times 10^{-7} \\
-\end{array}$ & $\begin{aligned} 7.1 & \pm 2.0 \\
11.7 & \pm 2.0^{\mathrm{a}} \\
6.2 & \pm 1.3 \\
4.7 & \pm 0.4\end{aligned}$ \\
\hline $\begin{array}{l}\text { D-Ala met enkephalin } \\
\text { D-Ala met enkephalin } \\
\text { D-Ala met enkephalin } \\
\text { None (control) }\end{array}$ & $\begin{array}{l}1.6 \times 10^{-9} \\
1.6 \times 10^{-8} \\
1.6 \times 10^{-7} \\
\quad-\end{array}$ & $\begin{array}{r}6.9 \pm 0.8 \\
12.9 \pm 1.4^{\mathrm{a}} \\
7.0 \pm 1.0 \\
4.6 \pm 0.4\end{array}$ \\
\hline $\begin{array}{l}\text { Morphine sulphate } \\
\text { None (control) } \\
\text { Morphine sulphate } \\
\text { ( } 5.5 \mathrm{mmol} / \mathrm{l} \text { glucose) } \\
5.5 \mathrm{mmol} / 1 \text { glucose } \\
\text { alone (control) }\end{array}$ & $\begin{array}{l}6.5 \times 10^{-8} \\
- \\
1.3 \times 10^{-7}\end{array}$ & $\begin{array}{l}7.4 \pm 0.9^{\mathrm{a}} \\
5.0 \pm 0.5 \\
3.4 \pm 0.5^{\mathrm{a}} \\
1.6 \pm 0.2\end{array}$ \\
\hline $\begin{array}{l}\text { Naloxone hydrochloride } \\
\text { Naloxone hydrochloride } \\
\text { Naloxone hydrochloride } \\
\text { Naloxone hydrochloride } \\
\text { None (control) }\end{array}$ & $\begin{array}{l}1.2 \times 10^{-8} \\
1.2 \times 10^{-7} \\
1.2 \times 10^{-6} \\
1.2 \times 10^{-5} \\
\quad-\end{array}$ & $\begin{array}{l}6.2 \pm 0.7 \\
6.7 \pm 0.8 \\
8.8 \pm 1.2^{\mathrm{a}} \\
7.9 \pm 1.1 \\
6.1 \pm 0.6\end{array}$ \\
\hline
\end{tabular}

${ }^{\mathrm{a}} \mathrm{p}<0.05$ compared to appropriate control (Student's ' $\mathrm{t}$ ' test)

were broadly similar to the response to DAMME (Table 1, Fig. 2). The concentrations of morphine sulphate which stimulated insulin release were in the same range as the stimulatory enkephalin concentrations (Table 1). Higher morphine sulphate concentrations $\left(6.5 \times 10^{-5} \mathrm{~mol} / \mathrm{l}\right)$, like enkephalin, decreased glucose stimulated insulin secretion in perifusion by $30 \%$ on average (result not shown). Naloxone hydrochloride alone produced a small significant $(p<0.05)$ stimulation of insulin release but at only one concentration (Table 1).

Islet perifusion showed that the stimulatory effect of opioid peptides and morphine sulphate was rapid. There was no 'second phase' insulin secretion despite continuous perifusion of the islets with enkephalin for $30 \mathrm{~min}$ (Fig. 2). However, the response to enkephalins or morphine sulphate was restored if the islets were perifused with medium containing glucose only (Fig. 3). Simultaneous exposure to naloxone largely prevents the stimulation of insulin release by enkephalin (Fig. 2). Although male Wistar rat islets were used in perifusion experiments, the results obtained in Figure 2 and Figure 3 were the same as those using islets from female Sprague-Dawley rats (Fig. 1 and Table 1). 


\section{Discussion}

We have presented evidence that an opiate-like peptide (D-Ala $\left./ \mathrm{MePhe}^{4} / \mathrm{Met} /(\mathrm{CO})-\mathrm{o} 1\right)$ enkephalin, DAMME, affects insulin secretion from isolated rat islets of Langerhans. Its effects were concentration dependent, stimulatory at low concentrations and inhibitory at high concentrations. Insulin secretion was also stimulated by met-enkephalin, which is known to have a short half life, and by a longer acting alanine substituted enkephalin [11]. Morphine sulphate also stimulated insulin release, while naloxone, a specific opiate antagonist, prevented or reversed the effects of enkephalins on islets during perifusion and during a $30 \mathrm{~min}$ static incubation. These results suggest that opiate receptors are present in islets. This possibility is further supported by the demonstration, by immunocytochemistry and radioimmunoassay that such receptors are present in pancreatic islets [12]. Furthermore, B-endorphin and

Fig. 2a-c. Insulin secretion from groups of 50 rat islets perifused for $40 \mathrm{~min}$ with medium containing $6 \mathrm{mmol} / 1$ glucose before the test substances were introduced (arrow). Test substances were: a Glucose $20 \mathrm{mmol} / 1$; DAMME $1.6 \times 10^{-8} \mathrm{~mol} / 1$. b D-Ala ${ }^{2}$ met enkephalin $1.6 \times 10^{-8} \mathrm{~mol} / \mathrm{l}$; enkephalin plus naloxone $1.2 \times$ $10^{-6} \mathrm{~mol} / 1$. c Met enkephalin $1.6 \times 10^{-8} \mathrm{~mol} / 1$; morphine sulphate $6.5 \times 10^{-8} \mathrm{~mol} / \mathrm{l}$. The enkephalins and morphine sulphate were made up in medium containing $6 \mathrm{mmol} / 1$ glucose. Results of one experiment are shown, similar results having been obtained in 4 experiments

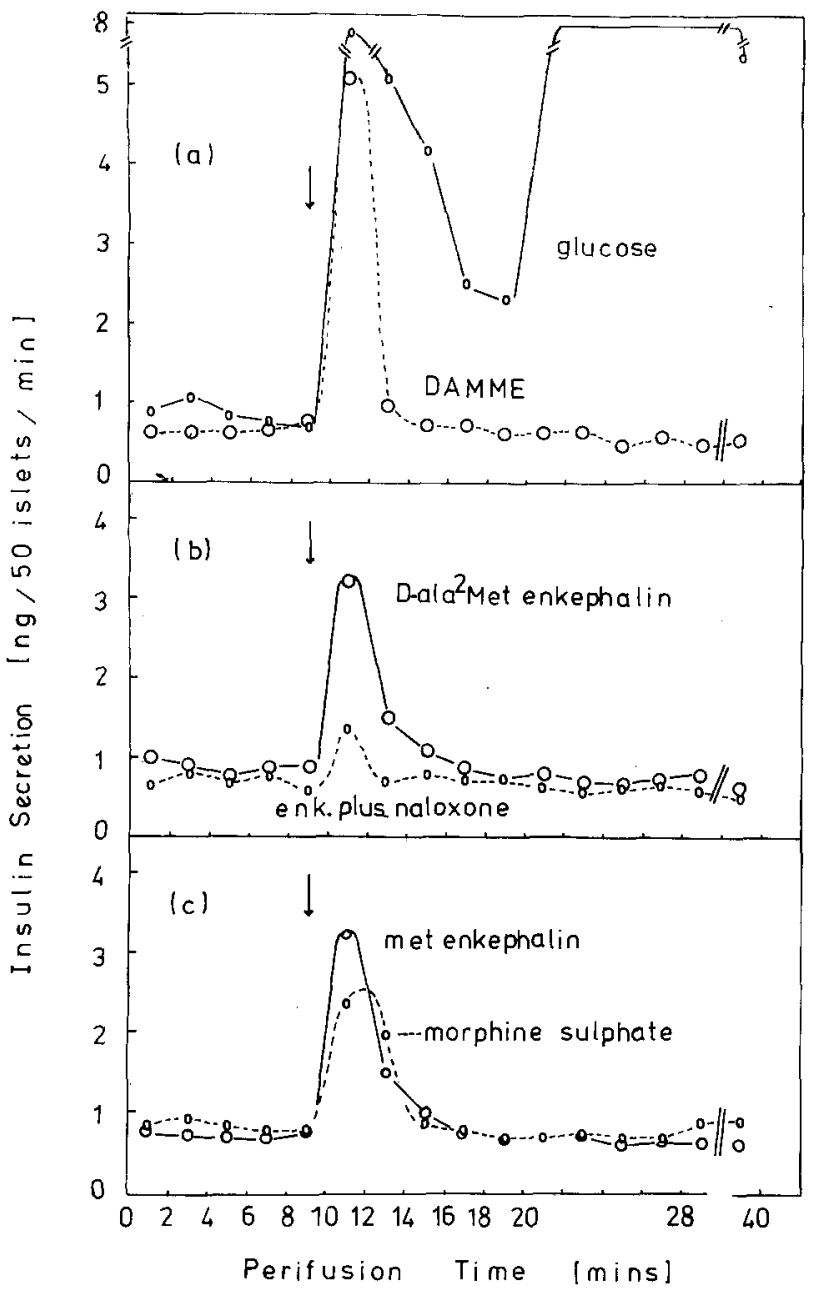

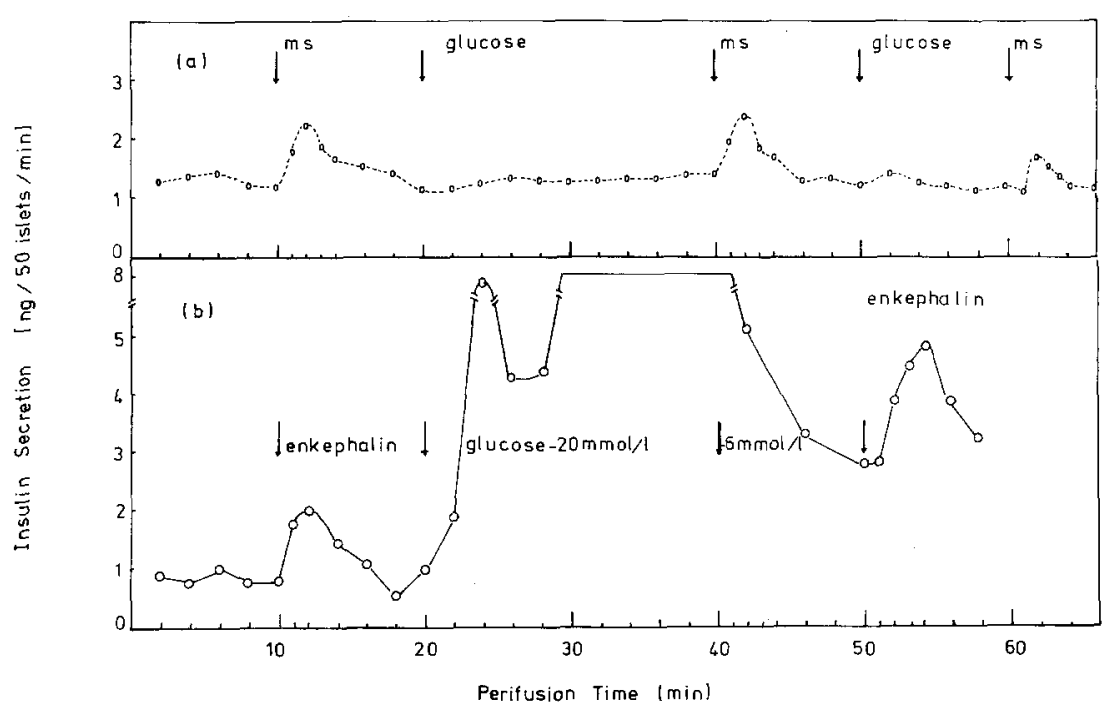

Fig. 3a and b. Insulin secretion from groups of 50 islets perifused for $40 \mathrm{~min}$ with medium containing $6 \mathrm{mmol} / \mathrm{l}$ glucose before the test substances were introduced (arrows). Test substances were: a Morphine sulphate (ms) $6.5 \times 10^{-8} \mathrm{~mol} / 1$, and glucose $6 \mathrm{mmol} / \mathrm{l}$. b Met-enkephalin, $1.6 \times 10^{-8} \mathrm{~mol} / 1$, glucose $20 \mathrm{mmol} / 1$, and $6 \mathrm{mmol} / \mathrm{l}$ followed by ala-substituted met enkephalin $1.6 \times 10^{-8} \mathrm{~mol} / 1$ Similar results were obtained in three experiments 
morphine have been shown to affect hormone release from the perfused dog pancreas, perhaps via opiate receptors [6].

The rapidity of the secretory response of perifused islets to stimulation by enkephalins and morphine suggests an effect on ion movement, perhaps on calcium uptake. Ipp and co-workers suggested that morphine and B-endorphin stimulated insulin and glucagon release in the perfused pancreas by a simultaneous inhibition of somatostatin release [6]. The inhibitory effects of somatostatin on hormone release are demonstrable in the perfused pancreas, though there is some doubt as to whether they are to be found in collagenase isolated islets [13]. If this latter is the case, then it is unlikely that our results could be explained by inhibition of somatostatin release. However, it has also been shown by BentHansen et al. [14] that one of the effects of somatostatin in isolated mouse islets is an inhibition of the first phase of glucose induced insulin release, and that excess $\mathrm{Ca}^{++}$can reverse this inhibition. It is therefore conceivable that opioid peptides affect islet insulin release via complex interactions with somatostatin and calcium.

The results we have obtained with enkephalins and isolated islets agree in certain respects with those of Ipp and co-workers using B-endorphin and the perfused dog pancreas [6]. The timing of the response and the concentrations of opioid peptide which stimulate insulin release are similar in the two systems. The results do not agree with the observations of Kanter and others [15] using monolayer cultures of B-cells.

Two points emerge. Firstly, the response to enkephalin and morphine in perifusion was rapid and transitory, only returning when a period intervened between enkephalin challenges (Fig. 3). The enkephalin response was smaller than the first phase of insulin release which can be stimulated by a maximal glucose challenge $(20 \mathrm{mmol} / 1$ glucose $)$. The short duration of the response may result from the breakdown of enkephalins by islet peptidases, although this seems unlikely in the perifusion system, or, it may indicate the rapid development of tolerance to these opioid peptides. It is also conceivable that the single response in perifusion in vitro may be reversed by some endogenous factor in vivo. Secondly, our observations may be relevant to the aetiology of non-insulin dependent diabetes, where the pancreas is essentially histologically normal, and the disease may be regarded as a disorder of the control of insulin release [16]. Many patients with non-insulin dependent diabetes show CPAF and are apparently more than normally sensitive to the effects of enkephalin, at least in this respect. The dose reversi- bility of the effect of enkephalin on insulin release suggests a possible way in which non-insulin dependent diabetes might be produced, namely that a concentration of enkephalin which in normal people would stimulate the release of insulin might in these patients inhibit it. This highly speculative hypothesis could be tested in clinical studies.

Acknowledgements. We thank Dr. B. von Graffenried, Sandoz, Basle for supplies of DAMME, and the Medical Research Council and Wellcome Trust for financial support.

\section{References}

1. Leslie RDG, Pyke DA (1978) Chlorpropamide-alcohol flushing: a dominantly inherited trait associated with diabetes. $\mathrm{Br}$ Med J II: 1519-1521

2. Leslie RDG, Barnett AH, Pyke DA (1979) Chlorpropamide alcohol flushing and diabetic retinopathy. Lancet I: 997-999

3. Leslie RDG, Pyke DA, Stubbs WA (1979) Sensitivity to enkephalin as a cause of non-insulin dependent diabetes. Lancet I: 341-343

4. Feldberg W, Gupta K (1974) Morphine hyperglycaemia. J Physiol (Lond) 238: 487-502

5. Feldberg W, Smyth DG (1977) Chemical transmitter at synapses in a sympathetic ganglion. Br J Pharmacol 60: 445

6. Ipp E, Dobbs R, Unger RH (1979) Morphine and $\beta$-endorphin influence the secretion of the endocrine pancreas. Nature 276 : 190-191

7. Polak JM, Sullivan SN, Bloom, SR, Facer P, Pearse AGE (1977) Enkephalin-like immuno-reactivity in the human gastrointestinal tract. Lancet II: 972-974

8. Howell SL, Taylor KW (1978) Potassium ions and the secretion of insulin by islets of Langerhans incubated in vitro. Biochem J 108: 17-24

9. Green IC, Taylor KW (1972) Effects of pregnancy in the rat on the size and insulin secretory responses of the islets of Langerhans. J Endocrinol 54: 317-325

10. Gey MK, Gey GO (1936) Maintenance of human normal cells and tumour cells in continuous culture. Am J Cancer 27: 45-76

11. Pert CB, Bowie DL, Fong BTW, Chang J-K (1976) Synthetic analogues of met-enkephalin which resist enzymatic destruction. In: Kosterlitz HW (ed) Opiates and endogenous opioid peptides. Elsvier, Amsterdam, p 79-85

12. Bruni JF, Watkins WB, Yen SSC (1979) $\beta$-endorphin in the human pancreas. J Clin Endocrinol Metab 49: 649-651

13. Feldman JM (1979) Species variation in the islets of Langerhans. Diabetologia 16: 1-4

14. Bent-Hansen I, Capito K, Hedescov CJ (1979) The effect of calcium on somatostatin inhibition of insulin release and cyclic AMP production in mouse pancreatic islets. Biochim Biophys Acta 585: 240-249

15. Kanter R, Ensinck, J, Fujimoto W (1979) Disparate effects of enkephalin and morphine upon insulin and glucagon secretion in islet cell cultures. Diabetes 29: 84-86

16. Pyke DA (1979) Diabetes: The genetic connections. Diabetologia 17: 333-343

Received: March 17, 1980,

and in revised form: May 2, 1980

Dr. I. Green

Department of Biochemistry

School of Biological Sciences

The University of Sussex

Falmer, Brighton BN1 9QG, Sussex

England 